\title{
Monika Skura
}

Uniwersytet Warszawski

\section{Relacje nauczyciela wspomagającego i nauczyciela wiodącego - temat wciąż otwarty}

Model wspólnej edukacji uczniów ze specjalnymi potrzebami edukacyjnymi (SPE) razem z uczniami pełnosprawnymi w klasie integracyjnej stał się coraz bardziej popularny wśród dzieci ze SPE i ich rodziców. Model ten stanowi wyzwanie dla nauczycieli. Praca w klasach integracyjnych opiera się na potrzebie współpracy pomiędzy nauczycielami regularnymi i wspierającymi, ale może to powodować trudności i często napotykać problemy. Artykuł jest prezentacją badań koncentrujących się na cechach udanej pracy zespołowej. Uczestniczyło w nim 19 uczestników - nauczyciele ogólni i wspierający, studenci studiów podyplomowych oraz studenci studiów drugiego stopnia. Dane zebrane podczas wywiadów w grupach fokusowych prowadzą do następujących wniosków: respondenci reprezentują pogląd, że obowiązkowe jest współtworzenie ogólnych zasad współpracy, wskazują na potrzebę relacji partnerskich, aby działania były skuteczne.

Słowa kluczowe: relacja, nauczyciel wspomagający, nauczyciel wiodący, edukacja inkluzyjna, szkoła integracyjna

\section{The relationship between general and supporting teachers - a (still) open debate}

The model of inclusive education has become increasingly popular for children with SEN and their parents. For teachers working in inclusive or integrative classrooms is linked with a demand of coordination and collaborative relationship between regular and special-education/supporting teachers, yet it might cause some difficulties and often encounters problems. The article is a presentation of a study focused on attributes of successful teamwork. It involved 19 participants - general and supporting teachers, post - graduate students and master's degree students. Data collected in focus group interviews have raised the following findings: respondents suppose obligatory co-creating general rules of collaboration as well as necessity of equal partners relationship to operate successful and effective.

Keywords: relationship, supporting teacher, general teacher, inclusive education, integrative school 


\section{Wprowadzenie}

Edukacja integracyjna (integracja $w$ edukacji) oraz integracja włączająca (model "szkoły dla wszystkich”) to formy kształcenia, z których coraz chętniej korzystają uczniowie ze specjalnymi potrzebami edukacyjnymi (SPE). Jak wskazują autorzy [Szumski 1996, 2006; Gajdzica 2010; Chrzanowska, Jachimczak 2015], założenia edukacji integracyjnej i poszukiwania teoretycznych podstaw dydaktyki inkluzyjnej charakteryzują się nadal niejednoznacznością rozwiązań praktycznych. Złożoność idei wspólnej nauki wszystkich uczniów napotyka bowiem wiele trudności na poziomie systemu edukacji, form kształcenia, rozwiązań edukacyjno-wychowawczych i kadry dydaktycznej.

Rozróżnienie możliwości budowania procesu edukacyjnego wokół specyficznych potrzeb ucznia, tj. rozumienia edukacji włączającej jako synonimu kształcenia integracyjnego lub odmiany tego kształcenia (kształcenie integracyjne lub poszerzona odmiana takiego kształcenia) odnośni się do zasad organizacji kształcenia. Edukacja włączająca jest umieszczana w ramach pedagogiki ogólnej, a kształcenie integracyjne jest jedną z form nauczania specjalnego [Szumski 2010; Gajdzica 2007].

W modelu integracyjnym do mniej licznej klasy przyjmuje się kilkoro uczniów z niepełnosprawnością. Dodatkowy nauczyciel (nauczyciel wspomagający) wspiera dążenia dziecka w najpełniejszym realizowaniu zaplanowanego materiału. Założeniem podejścia włączającego jest natomiast to, że uczniowie z niepełnosprawnością są przyjmowani do szkół masowych, znajdujących się blisko miejsca zamieszkania. Powszechny system oświaty ma na celu wspieranie wszystkich uczniów i zapewnianie im optymalnych warunków do nauki [Szumski 2006; Sipowicz, Pietras 2017]. Koncepcja systemu edukacji - koncentracja na specjalnych potrzebach ucznia ze SPE lub postrzeganie obecności uczenia niepełnosprawnego jako pełnoprawnego odbiorcy edukacji - pokazuje sposób myślenia o osobach z niepełnosprawnością oraz o ich miejscu w społeczeństwie.

Możliwość realnej przemiany szkół w taki sposób, aby kadra w niej ucząca podchodziła do każdego dziecka w sposób możliwie jak najbardziej zindywidualizowany i elastyczny wiąże się z koncepcją szkolnictwa, a w praktyce dotyczy ustanowionych aktów prawnych, które regulują organizowanie kształcenia, wychowania i opieki dla uczniów ze SPE oraz kwalifikacji nauczycieli. W nowym rozporządzeniu MEN z dnia 9 sierpnia 2017 roku [Dz. U. z 2017 r., poz. 1578] ustawodawca zapewnił obecność dodatkowych nauczycieli posiadających kwalifikacje z zakresu pedagogiki specjalnej (w domyśle nauczycieli wspomagających) w celu współorganizowania kształcenia integracyjnego w szkołach i klasach integracyjnych oraz w szkołach ogólnodostępnych, ale w tych ostatnich tylko w pracy 
z dziećmi z autyzmem, w tym z zespołem Aspergera lub z niepełnosprawnością sprzężoną. Zatrudnienie drugiego nauczyciela w szkolnictwie ogólnym w pracy z dziećmi z inną niepełnosprawnością, które posiadają orzeczenie o potrzebie kształcenia specjalnego, jest możliwe tylko za zgodą organu prowadzącego. Istnieje również ewentualność zrezygnowania z zatrudnienia drugiego nauczyciela na rzecz innego specjalisty lub asystenta, lub pomocy nauczyciela.

Sposób działania dwóch pedagogów ma polegać według rozporządzenia na wspólnym prowadzeniu zajęć edukacyjnych, grup wychowawczych i pracy wychowawczej, uczestniczeniu w zajęciach edukacyjnych oraz w zintegrowanych działaniach i zajęciach określonych $\mathrm{w}$ programie, $\mathrm{w}$ doborze form i metod pracy z uczniami ze SPE. Warto zaznaczyć, że o ile kwalifikacje do zajmowania stanowiska nauczyciela w szkolnictwie specjalnym są jasno sprecyzowane, o tyle ujęte możliwości zatrudnienia nauczyciela do pracy z uczniami ze SPE w innych formach edukacji ograniczone jest do sformułowania, że stanowisko to może zajmować nauczyciel pedagog, który skończył studia wyższe lub podyplomowe na kierunku pedagogika w specjalności odpowiadającej prowadzonym zajęciom [Rozporządzenie MEN z dnia 1 sierpnia 2017 r., poz. 1575].

Wydaje się, że obecne przepisy prawne z jednej strony idą w kierunku umożliwienia dziecku niepełnosprawnemu uczęszczania do szkoły ogólnodostępnej, z drugiej zaś, dookreślają zasadność istnienia ścieżki szkolnictwa specjalnego. Opisywanie założeń edukacji włączającej budzi pytania dotyczące istnienia wielopoziomowego modelu nauczania dzieci ze SPE, uwspólniania i zróżnicowania procesu kształcenia uczniów sprawnych i niepełnoprawnych oraz odpowiednio przygotowanej kadry. Nauczyciel prowadzący klasę w tym modelu nie zawsze może liczyć na specjalistyczną pomoc ze strony nauczyciela wspomagającego, jak to ma miejsce w klasie/szkole integracyjnej. Musi zatem mieć odpowiednie przygotowanie do pracy z każdym uczniem ze SPE, który może pojawić się w jego klasie. Codzienna praktyka i autorzy publikacji [Szumski 2014; Sadowska 2016] potwierdzają, że Polska szkoła wciąż nie jest gotowa na "edukację dla wszystkich". Szkoły integracyjne, w których można realizować obwiązek szkolny wraz z uczniami sprawnymi, cieszą się dużym zainteresowaniem, a nawet, jak pokują badania, wciąż brakuje w nich miejsc [Chrzanowska 2015].

W literaturze przedmiotu, w odniesieniu do nauczycieli pracujących $w$ tym modelu, tj. w klasie integracyjnej, możemy znaleźć zagadnienia opisujące kwalifikacje, kompetencje, zadania, role nauczycieli, a w tym szczególnie te opisujące pracę nauczyciela wspomagającego. W zakresie kompetencji nauczycieli pracujących $\mathrm{w}$ grupach/klasach integracyjnych autorzy piszą o konieczności posiadania wiedzy o specyfice rozwoju dziecka ze SPE, znajomość metod i technik pracy oraz odpowiednich cechy osobowości [Bayliss 1996; Koć-Seniuch 2000; Palak, Bujnowska 2008; Bąbka 2001; Kędzierska 2010; Gajdzica 2011; Al-Khamisy 2013, 
Apanel 2014]. Niewiele jest natomiast publikacji wskazujących obszary funkcjonowania we wspólpracy dwóch pedagogów w klasie, z pokreśleniem tego, co w tych działaniach jest „wspólne, a co swoiste” [Hulek 1988; Dryżałowska 2001].

Wyzwania zawodowe nauczycieli pracujących w klasie integracyjnej obejmują: zadania związane z nauczaniem (plany, programy, podręczniki) i ich dostosowaniem, czynności integrujące klasę oraz promujące założenia edukacji włączającej (dzieci w klasie i w szkole, rodziców, społeczności pozaszkolne), jak również działania diagnostyczne oraz wychowawcze i wspierające wszystkich uczestników procesu. Do obowiązków pedagogów pracujących z dziećmi ze SPE należy też prowadzenie rozległej dokumentacji i podejmowanie działań z instytucjami współpracującymi ze szkołą.

Różnorodność, wielość i specyfika zadań do wykonania powodują, że zarówno nauczyciele wiodący, jak i nauczyciele wspomagający nie czują się odpowiednio przygotowani to pracy zespołowej w klasie integracyjnej. $Z$ jednej strony, zgłaszają brak wiedzy praktycznej (częściej nauczyciele wiodący), z drugiej zaś, obawiają się utraty tożsamości zawodowej (pedagodzy specjalni) i drugorzędnej pozycji w zespole (nauczyciele wiodący). Cześć nauczycieli zauważa też negatywne aspekty procesu włączania, takie jak złożona sytuacja metodologiczna, zły dobór uczniów, trudna współpraca z rodzicami dzieci ze SPE. Co więcej, niektórzy pedagodzy nadal odczuwają brak wewnętrznej akceptacji integracyjnego systemu wychowania i nauczania [Gajdzica 2011; Staczewska, Hodkinson, Adams 2012; Chrzanowska 2015].

Idee edukacji włączającej i integracyjnej skłaniają do refleksji nad systemem funkcjonowania szkoły. Skuteczność tych koncepcji zależy przede wszystkim od postaw i nastawienia osób odpowiedzialnych za edukację, czyli, w pierwszym rzędzie, nauczycieli. Koncepcja wspólnego uczenia się wszystkich uczniów postuluje zmianę postaw mentalnych i kierunków postrzegania roli pedagoga. Według założeń ma on wyróżniać się refleksyjnym myśleniem, poszukiwaniem nowych rozwiązań, rozumieniem zmieniających się strategii ucznia oraz umiejętnością stosowania zasad dobrego partnerstwa na rzecz podnoszenia efektywności wspólnego działania. W polskiej literaturze przedmiotu stosunkowo niewiele jest publikacji [Rzedzicka 2000; Bobińska-Domżał 2014] poświęconych badaniom, które wskazywałyby praktyczne rozwiązania i uwarunkowania korzystnej pracy zespołowej na lekcji, podczas gdy temat ten jest często podejmowany za granicą [Bauwens, Hourcade, Friend 1989; Fielding-Barnsley 2005; Douglas, Chapin, Nolan 2015; Scott 2017].

Intencją przeprowadzonego badania była więc próba ustalenia, co warunkuje satysfakcjonujące relacje pomiędzy nauczycielem wiodącym, a nauczycielem wspomagającym w klasie integracyjnej. $\mathrm{W}$ tym celu przeprowadzono badanie fokusowe w grupie nauczycieli wiodących, nauczycieli wspomagających, słucha- 
czek studiów podyplomowych $\mathrm{w}$ zakresie edukacji integracyjnej dzieci z niepełnosprawnościami oraz studentek pedagogiki w obszarze edukacji integracyjnej i edukacji włączającej.

\section{Opis badania}

Zdaniem autorów literatury metodologicznej [Dukaczewska-Nałęcz 1999; Konecki 2000; Maison 2001; Lisek-Michalska 2013], sytuacja wywiadu grupowego jest podobna do kontekstu realnie występującego w życiu społecznym. W wyniku interakcji z innymi ludźmi następuje wymiana opinii, spostrzeżeń, kształtowanie się przekonań, odsłanianie własnych odczuć, skojarzeń. Specyfika i dynamika zogniskowanych spotkań w grupie umożliwia uzyskanie w krótkim czasie informacji na temat wzorów myślenia przedstawicieli danej społeczności, definicji sytuacji, znaczeń, interpretacji zjawisk oraz o używanym przez daną grupę słownictwie.

Przygotowanie i przeprowadzenie wywiadu grupowego ma bardzo indywidualny charakter, bez zdefiniowanych zasad jego wykorzystania. Liczba uczestników zależy od założeń metodologicznych. Grupę tworzą osoby, które posiadają jakieś podobne właściwości, są nimi np.: zbliżony status społeczny, materialny lub to, że przebywają na określonym stanowisku. Posiadanie wspólnych cech ułatwia integrację, stwarza poczucie wspólnoty i atmosferę zaufania odpowiednią dla wyrażania własnych myśli i odczuć oraz umożliwia poznanie opinii innych ludzi [Krueger 1994; Maison 2001].

Aby poznać wzajemne oczekiwania, potrzeby i zapatrywania pedagogów na temat zadowalających interakcji między nauczycielem wiodącym, a nauczycielem wspomagającym w klasie integracyjnej, $w$ wypowiedziach badanych obecnych na spotkaniach fokusowych szukano informacji odnoszących się do następujących kwestii:

1. Jakie cechy, istotne w pracy w klasie integracyjnej, powinien posiadać: A) nauczyciel wspomagający; B) nauczyciel wiodący?

2. Jakie są ważne aspekty wsparcia i pomocy, jakie powinien udzielać: A) nauczyciel wspomagający; B) nauczyciel wiodący w klasie integracyjnej?

3. Czym charakteryzują się przykłady dobrej współpracy nauczycieli w klasie integracyjnej;

4. Jakie sugestie i praktyczne podpowiedzi mogłyby poprawić współpracę nauczyciela wspomagającego i wiodącego w klasie integracyjnej?

Ogólny problem badawczy - warunki satysfakcjonujących relacji pomiędzy nauczycielem wiodącym, a nauczycielem $\mathrm{w}$ wspomagającym $\mathrm{w}$ klasie integracyj- 
nej - został przełożony na szereg problemów szczegółowych, które dotyczą cech nauczycieli, aspektów wspólpracy i wsparcia. Operacjonalizacja problemu badawczego w kontekście zogniskowanych wywiadów grupowych polegała więc na przygotowaniu odpowiedniego scenariusza, $\mathrm{w}$ którym zaproponowane pytania oraz stwierdzenia wymagały komentarza ze strony badanych, a następnie podzieleniu uzyskanego materiału na kluczowe kategorie. Przygotowany scenariusz wywiadu składał się z pięciu części, zawierających poszczególne obszary tematyczne. Były nimi: 1) Wprowadzenie, 2) Osobowość nauczyciela (wiodącego, wspomagającego), 3) Wsparcie udzielane sobie przez nauczycieli: wiodącego i wspomagającego, 4) Współpraca nauczycieli w klasie integracyjnej, 8) Zakończenie.

Przeprowadzone badania pokazały, że wszystkie osoby biorące udział w badaniach były bardzo zainteresowane tematyką dotyczącą zakresu, jakości i poprawności relacji w klasie nauczycieli wiodących i wspomagających. Widziały potrzebę zainicjowania szerszej dyskusji na temat tego, co zrobić, aby ta współpraca była udana, a w konsekwencji miała pozytywny wpływ na integrację dziecka ze SPE. Spostrzeżenia, uwagi i postulaty badanych odnosiły się również do systemowego ujęcia kształcenia integracyjnego, edukacji nauczycieli oraz powinności dyrektorów szkół i decydentów zarządzających oświatą. Każde zaplanowane badanie fokusowe trwało około godziny i przebiegało w miłej atmosferze. Łącznie wzięło w nim udział 19 osób w wieku od 24 do 45 lat. Chronologicznie pierwszą grupę stanowiła pięcioosobowa grupa słuchaczek studiów podyplomowych. Drugie i trzecie w kolejności spotkanie fokusowe odbyło się wśród nauczycieli wspomagających (pięć osób), a następnie wiodących (cztery osoby). Ostatni wywiad, $\mathrm{w}$ grupie pięcioosobowej, został przeprowadzony ze studentkami ostatniego roku studiów magisterskich. Badani zostali poinformowani o celu badania i o rejestrowaniu ich wypowiedzi na dyktafonie.

W wywiadzie fokusowym wzięły udział dwie grupy nauczycieli z jednej z warszawskich szkół podstawowych: pierwszą stanowili nauczyciele wspomagający, a drugą nauczyciele wiodący. Wśród badanych osób było osiem kobiet i jeden mężczyzna - nauczyciel wiodący. Staż pracy, w przypadku nauczycieli wspomagających wynosił od 20 lat do kilku miesięcy, a czas współpracy z nauczycielem wiodącym od 4 lat do 3 miesięcy. Staż pracy nauczycieli wiodących, biorących później udział w rozmowie, to od 5 do 9 miesięcy i podobny czas współpracy z nauczycielem wspomagającym. Zarówno nauczyciele wspomagający, jaki wiodący, pracują przede wszystkim z dziećmi z autyzmem, z Zespołem Aspergera, niedostosowaniem społecznym oraz z dziećmi z niepełnosprawnością ruchową, intelektualną i ADHD.

Słuchaczki studiów podyplomowych to nauczyciele wiodący, nauczyciele wiodący w przeszłości, którzy obecnie są asystentami, albo asystenci, którzy pracują w klasach integracyjnych. Wszyscy po skończeniu studiów chcą być nauczy- 
cielami wspomagającymi w klasach integracyjnych. Jednym z powodów zaproszenia do badania tej grupy było to, że osoby te mają duże doświadczenie w pracy w szkole i już pewne "zaplecze teoretyczne" z zakresu edukacji inkluzyjnej. Ponadto słuchaczki były w trakcie praktyk, a przez to reprezentują szersze spojrzenie na problem wspólpracy nauczycieli.

Odwrotna sytuacja ma miejsce w przypadku studentek - są one na ostatnim roku studiów i w przyszłości chcą być nauczycielami wspomagającymi. Nie mają one jeszcze dużo doświadczenia zawodowego, ale studiowały kilka lat teorie kształcenia integracyjnego. Oprócz znajomości literatury przedmiotu miały również możliwość obserwowania zajęć lekcyjnych podczas odbywania praktyk. Ich punkt widzenia wydaje się interesujący, ponieważ może wnieść pewnego rodzaju "świeże spojrzenie" na procesy przebiegające w klasie integracyjnej. Studentki uczestniczące $\mathrm{w}$ fokusie hospitowały pracę $\mathrm{w}$ klasie, $\mathrm{w}$ których byli uczniowie z autyzmem, zespołem Aspergera, niepełnosprawnością intelektualną w stopniu lekkim i z ADHD.

\section{Prezentacja wyników i analiza zebranego materiału}

Przeprowadzone wywiady zostały poddane transkrypcji, a następnie poddanej jakościowej interpretacji. Podstawę interpretacji danych stanowił odpowiedni klucz kategoryzacyjny. Wyniki badań fokusowych zostały opatrzone przykładami wypowiedzi respondentów. Interpretacja zebranego materiału - zgodnie z założeniami teorii hermeneutycznej [Ablewicz 2010; Kubinowski 2010] - ma charakter wielopoziomowy. Na początku przedstawione zostaną dane „obiektywne", czyli zapisy poszczególnych wypowiedzi. Następnie będzie dokonana interpretacja pierwszego stopnia, czyli interpretacje samych osób badanych oraz interpretacja drugiego stopnia, czyli ugruntowany teoretycznie komentarz badacza. Dodatkowo każda z kategorii została uzupełniona o tabele (zastawienie tematyczne), które w sposób szczegółowy przedstawiają wymieniane przez badaczy istotne, ich zdaniem, elementy wzajemnych relacji nauczycieli.

\section{A. Osobowość nauczycieli pracujących w klasie integracyjnej}

Nauczyciel jest nieodzownym ogniwem procesu nauczania i wychowania. Zdaniem autorytetu [Grzegorzewska 1996; 1989] to osobowość nauczyciela warunkuje skuteczność wszelkich oddziaływań wychowawczych. Pedagog ma wzbogacać wiedzę swoich wychowanków, rozbudzać zainteresowania, rozwijać ich zdolności i zalety charakteru oraz zwalczać wady. W badaniu zapytano zatem, jakie cechy nauczycieli są ważne w pracy w zespole integracyjnym. 
Jak pokazują otrzymane wyniki zdaniem nauczycieli wspomagających, duże znaczenie $\mathrm{w}$ ich działaniach, oprócz wykształcenia, ma doświadczenie $\mathrm{w}$ pracy z dziećmi ze SPE, a następnie umiejętności interpersonalne i otwartość na współpracę z nauczycielem wiodącym. Wykształcenie im wyższe tym lepiej, zdaniem badanych, ponieważ „im więcej się wie o różnych rodzajach niepełnosprawności, tym lepiej". Ponadto doświadczenie ma również bardzo istotne znaczenie, bo "taka osoba jest w stanie lepiej przewidzieć, w którą stronę dziecko ma iść". Gotowość na współdziałanie, w opinii nauczycieli wspomagających, to umiejętność "dogadania się", myślenie, że „działamy na rzecz dobra dziecka, a pracujemy $\mathrm{w}$ teamie, a nie realizujemy swoje ambicje, bo ci tu teraz pokażę".

W opinii nauczycieli wiodących natomiast, istotne cechy nauczyciela wspomagającego to umiejętność współpracy oraz cechy osobowe takie jak: tolerancja, spostrzegawczość, zaangażowanie, wykazywanie inicjatywy („powinien być tolerancyjny wobec naszego zachowania, bo wszyscy jesteśmy ludźmi i każdy powinien uczyć się wzajemnych zachowań"; "nauczyciel wspomagający widzi na lekcji to, czego ja nie widzę"; ",ważne jest, żeby mu się chciało, (żeby - M.S.) był zaangażowany w tok lekcji i wiedział, kiedy ma działać"). Nauczyciele wiodący objaśniają też, dlaczego takie postawy są ważne w ich wspólnej pracy („kiedy ja ogarniam cały temat to nie widzę tego, co ona widzi będąc z boku”, ,"ona zmienia miejsce w klasie na lekcji więc widzi lepiej, kto pracuje, a kto nie, komu trzeba pomóc; poza tym ona lepiej zna dzieci z trudnościami"). Badani podkreślali również konieczność nawiązywania osobistych relacji poza szkołą, jako możliwość lepszego poznania się, które zawsze prowadzi do lepszego współdziałania na lekcji („,musimy się nawzajem poznać, najlepiej na kawie”). Wyjaśniają też, dlaczego to jest ważne w ich pracy (,jjesteśmy cały dzień razem, musimy się dobrze znać, bo praca nas stawia w bardzo różnych sytuacjach"; ",ona wie, jak ja reaguję, a ja znam ją; kiedy ja jestem zdenerwowana, lepiej, żeby ona zaczęła rozmowę z rodzicem"; "dzieci i rodzice wybierają nauczyciela, który jest dla nich wygodny, musimy wyczuwać, co druga myśli i jakby postąpiła").

Słuchaczki studiów podyplomowych, oprócz umiejętności współpracy, na drugim miejscu również podkreślały konieczność posiadania odpowiednich cech osobowości, tj. takt, cierpliwość, otwartość i wskazywały, dlaczego są one istotne („,ważne, żeby nauczyciel wspomagający wiedział, kiedy ma wykazać się wiedzą i umiejętnościami"; „,bo jak ktoś jest zdolny do kompromisów to ludzie zawsze się dogadają"). Studentki zaś wskazywały umiejętności komunikacyjne oraz, co ciekawe, konieczność zwiększania poczucia wartości nauczyciela wspomagającego i wzmocnienia jego kompetencji. Jednocześnie stwierdziły, że ta "uległość" nauczyciela wspomagającego może wynikać czasami z "jego wygody" i małego zaangażowania $\mathrm{w}$ procesy nauczania i wychowania. 
Cechy, które powinien posiadać nauczyciel wiodący, aby współpraca w klasie integracyjnej była bardziej korzystna, zdaniem nauczycieli wspomagających, to przede wszystkim otwartość na potrzeby dziecka z SPE. W ich opinii, doświadczenie i staż pracy mają w tego typu pracy mniejsze znaczenie („może być bez doświadczenia, byleby chciała się uczyć o potrzebach naszych dzieciaków z trudnościami”). Swoje przekonanie tłumaczą tym, że „często nauczyciel wspomagający ma więcej doświadczenia niż nauczyciel po edukacji początkowej i warto go wysłuchać". Co więcej, nauczyciele wiodący powinni też odpowiadać za efekty nauczania wszystkich dzieci, również tych ze SPE („chciałabym, żeby mój nauczyciel wiodący brał pod uwagę moje dzieciaki w toku lekcji, a nie, że ja mam na swych barkach piątkę z orzeczeniami").

Nauczyciele wiodący natomiast podkreślali, że, ich zdaniem, powinni oni wyrażać większą chęć współpracy, być bardziej otwarci na pomysły nauczyciela wspomagającego, a przede wszystkim, nie "stawiać siebie wyżej”, bo „słuchanie i szukanie wspólnego rozwiązania to podstawa". Nauczyciele argumentowali też, dlaczego taka postawa jest ważna (,jak będziemy nosili głowy do góry i myśleli, że nasze zdanie jest ważniejsze, to relacja się nie uda”; "przykład powinien iść z góry, my zawsze powtarzamy rodzicom, że jesteśmy na równi, żeby wiedzieli, że wszystko jedno, do kogo się zwrócą, wynik jest taki sam”).

Słuchaczki studiów podyplomowych, ponownie, podkreślały duże znaczenie umiejętności współpracy i wzajemnej życzliwości w zespole i wskazywały, dlaczego te cechy są istotne („umiejętność współpracy jest ważna, bo nauczyciel wiodący nie może o sobie myśleć, jako o wyznaczniku tego, co może się dziać"; „trzeba być otwartym, świeżym w relacji, a nie udawać, że drugiego nauczyciele w klasie nie ma”; "czasami u nauczyciela wiodącego pojawia się zazdrość o uczucia dzieci, bo nauczyciel wspomagający jest bliżej dzieci”; „ważny jest pierwszy moment, kiedy wchodzę do klasy i nauczyciel mnie przedstawia dzieciom. Jak powie, że jestem na równi i że dzieci mnie mają tak samo słuchać, jak jej, wtedy czaję się w klasie na swoim miejscu, dzieci mnie słuchają"). Podkreślały one również znaczenie otwartości na nowe umiejętności i chęć uczenia się („nauczyciel wiodący powinien mieć elementarną wiedzę na temat dzieci ze SPE, ale [w razie potrzeby M. S.] musi przyznać, że czegoś nie wie”; „bo jeśli osoby są chętne to doświadczenie się nabędzie).

Te same cechy wskazywały studentki, zwracając również uwagę na konieczność wysłuchania opinii drugiej strony i, co bardzo ważne, nie traktowanie własnej osoby i własnych sądów jako mniej istotnych („ważne, żeby nauczyciel wspomagający wiedział, jak przekazać, czego oczekuje, z czym się nie zgadza, a nie, że czuje się gorszy”; "nie może być tak, że nauczyciel wspomagający zajmuje się swoimi dzieci, a wiodący swoimi, czyli resztą"; "powinien być świadomy swoich kompetencji i umieć wyrazić swoje zdanie, powiedzieć, że się nie zgadza"). Pod- 
kreślały też znaczenie partnerskich relacji i otwartość na naukę nowych informacji dotyczących specyfiki funkcjonowania dzieci ze SPE ze strony nauczyciela wiodącego ("powinien też zobaczyć pracę tego drugiego nauczyciela"; „,nie powinien tworzyć sztucznej hierarchii, przecież są na równi"; ",nie ma wiedzy i doświadczenie w pracy z dziećmi niepełnosprawnymi, więc nich da się nauczyć"). Studentki dodają też proste wytłumaczenie, dlaczego obecność takich cech i postaw jest konieczna - „inaczej ta cała integracja nie ma sensu”.

Zestawianie tematyczne odpowiedzi osób badanych pokazuje tabela 1 .

Tabela 1. Cechy nauczycieli, które są istotne w pracy w klasie integracyjnej

\begin{tabular}{|c|c|c|c|}
\hline \multicolumn{4}{|c|}{ Cechy wsparcia nauczyciela wspomagającego } \\
\hline $\begin{array}{l}\text { Nauczyciele } \\
\text { wspomagający }\end{array}$ & $\begin{array}{c}\text { Nauczyciele } \\
\text { wiodący }\end{array}$ & $\begin{array}{l}\text { Słuchaczki studiów } \\
\text { podyplomowych }\end{array}$ & $\begin{array}{l}\text { Studentki ostatniego } \\
\text { roku studiów } \\
\text { magisterskich }\end{array}$ \\
\hline $\begin{array}{l}\text { - Wykształcenie, } \\
\text { kwalifikacje }\end{array}$ & $\begin{array}{l}\text { - Umiejętność } \\
\text { współpracy }\end{array}$ & $\begin{array}{l}\text { - Umejętność } \\
\text { współpracy }\end{array}$ & - Umiejętności komu- \\
\hline $\begin{array}{l}\text { - Doświadczanie } \\
\text { w pracy }\end{array}$ & $\begin{array}{l}\text { - Odpowiednie cechy } \\
\text { osobowe }\end{array}$ & $\begin{array}{l}\text { - Odpowienie } \\
\text { cechy osobowe }\end{array}$ & $\begin{array}{l}\text { - Odpowiedzialność } \\
\text { za całą klasę }\end{array}$ \\
\hline $\begin{array}{l}\text { - Umiejętności } \\
\text { interpersonalne } \\
\text { - Umiejętność } \\
\text { współpracy }\end{array}$ & $\begin{array}{l}\text { - Otwartość na osobi- } \\
\text { ste, pozainstytucjo- } \\
\text { nalne relacje }\end{array}$ & $\begin{array}{l}\text { - Otwartość na nowe } \\
\text { doświadczenia }\end{array}$ & $\begin{array}{l}\text { - Poczucie własnej } \\
\text { wartości i znaczenia } \\
\text { posiadania kompe- } \\
\text { tencji }\end{array}$ \\
\hline \multicolumn{4}{|c|}{ Cechy wsparcia nauczyciela wiodącego } \\
\hline $\begin{array}{l}\text { - Odpowiednie cechy } \\
\text { osobowe } \\
\text { - Odpowiedzialność } \\
\text { za całą klasę również } \\
\text { za uczniów z SPE }\end{array}$ & $\begin{array}{l}\text { - Odpowiednie cechy } \\
\text { osobowe (chęć do } \\
\text { współpracy, otwar- } \\
\text { tość na pomysły, } \\
\text { - Pilnowanie relacji } \\
\text { równoważnych }\end{array}$ & $\begin{array}{l}\text { - Umiejętnosć } \\
\text { współpracy } \\
\text { - Odpowiednie cechy } \\
\text { osobowe, postawy }\end{array}$ & $\begin{array}{c}\text { - Odpowiednie cechy } \\
\text { osobowe i postawy }\end{array}$ \\
\hline
\end{tabular}

Źródło: Opracowanie własne.

Wyniki przeprowadzonego badania pokazują, że osoby biorące udział w badaniu fokusowym oceniły, że bardzo istotne cechy osobowe nauczyciela wspomagającego to zaangażowanie, spostrzegawczość, otwartość, tolerancja, takt, cierpliwość oraz umiejętności: współpracy, interpersonalne i komunikacyjne. Wykształcenie, kwalifikacje i doświadczenie miały większe znaczenie dla samych nauczyli wspomagających, a poczucie własnej wartości i znaczenia posiadanych kompetencji dla studentek ostatniego roku studiów magisteriach. W odniesieniu do oceny istnych cech osobowych nauczyciela wiodącego największą rolę odgrywają takie właściwości, jak: otwartość, życzliwość, gotowość na partnerstwo, chęć uczenia się. Umiejętność współpracy i odpowiedzialność za całą klasę była przede wszystkim istotna dla nauczycieli wspomagających i słuchaczek studiów podyplomowych. 
Uzyskane dane pozwalają stwierdzić, że opinie badanych w większości pokrywają się z określeniami na temat dyspozycji, którymi powinien się kierować nauczyciela pracujący z dziećmi niepełnosprawnością zawartymi w publikacjach [Maciarz 1987; Maciarz 1992; Janiszewska-Nieścioruk 1999]. Istotne wydaje się, że u nauczyciele wspomagający częściej podkreślali umiejętność współpracy, a wiodący -otwartość na jej przyjęcie. Nauczyciele próbują znaleźć swoje miejsce, pomimo odmiennej ścieżki edukacyjnej i innych doświadczeń zawodowych. Wydaje się, że ciągle poszukują wzajemnej gotowości na wspólne budowanie społeczności klasowej.

\section{B. Wsparcie udzielane sobie przez nauczycieli pracujących}

w klasie integracyjnej

Obecność dwóch nauczycieli w klasie integracyjnej, w której bardzo często są dzieci z głębszymi niepełnosprawnościami, gdzie niekiedy jest „zły dobór uczniów", a współpraca z rodzicami nie jest łatwa, wymaga zgranego zespołu. W sytuacjach trudnych, stresujących, nowych dobrze jest liczyć na wsparcie partnera. Badani nauczyciele, słuchaczki studiów podyplomowych i studentki ostatniego roku studiów magisterskich zastali zapytani, na czym, ich zdaniem, polegałaby odpowiednia pomoc udzielana sobie nawzajem przez nauczyciela wspomagającego i wiodącego.

W odpowiedzi na pytanie, które dotyczyło sposobów wsparcia i potrzeby udziału w działaniach klasy integracyjnej, jakie poprzez swoją pracę powinien wnosić nauczyciel wspomagający, najwięcej osób z tej grupy podkreślało znaczenie wiedzy związanej ze specyfiką funkcjonowania dziecka ze SPE („,dzieci niepełnosprawne nie potrafią funkcjonować, jak dzieci zdrowe i nie można od nich wymagać, że zrobią coś w 45 minut i my to wiemy i niech [nauczyciele wiodący M.S.] uwierzą nam").

Zdaniem nauczycieli wiodących, realna pomoc, jaką powinni udzielać ci nauczyciele dotyczy wskazówek terapeutycznych w pracy z uczniami z SPE („nie wiemy, jak reagować $w$ sytuacjach bardzo stresujących, brakuje na doświadczenia w pracy z dziećmi z orzeczeniem"). Jednocześnie wskazywali, jakie działania poprawiają relacje („nawet te głupie dekoracje, to czasami wymaga 10 minut zostania dłużej po lekcjach; nauczyciel wspomagający niby nie musi, ale miło, jak można na niego liczyć"). Podkreślali też ich umiejętność reagowania na sytuacje trudne w klasie oraz zdolność włączania wszystkich dzieci w działania edukacyjno-społeczne przez zauważanie i eksponowanie ich mocnych stron (,ona zauważa to, czego ja nie widzę u dzieci z orzeczeniami"). Podkreślali też, dlaczego to jest tak ważne („,ona widzi więcej z boku, wie, jak zaangażować dzieci z niepełnosprawnością w to, co robi się na lekcji; jak (ona - M. S.) pomaga nie tylko dzieciom z trudnościami to nawiązuje się więź w klasie"). Wsparcie nauczycieli jest również 
niezbędne w chwilach obniżonej kondycji psychofizycznej, konieczności dostosowywania materiału, wystawiania ocen, czy rozmowy z rodzicami („ona wie, kiedy mam zły dzień i przejmuje pałeczkę, to bardzo pomaga"; , a z kwestią dostosowań, ja bym się nie potrafiła odnaleźć, więc dobrze, że się wymieniamy").

Słuchaczki studiów podyplomowych wskazywały podobne elementy wsparcia ze strony nauczyciela wspomagającego, szczególnie zaś podkreślały ich znaczenie w procesach integrujących klasę i zaznaczyły dlaczego ("nauczyciel wspomagający jest trochę takim animatorem grupy"; "zna mocne strony uczniów z SPE, a przez to wspiera jego zaistnienie w grupie"). Te same aspekty wsparcia wskazywały studentki ostatniego roku studiów, które w przyszłości chcą być nauczycielami wspomagającymi. Ich zdaniem, nauczyciele wspomagający to eksperci od sytuacji trudnych oraz strażnicy działań integracyjnych i włączających („przecież taki nauczyciel ma specjalistyczną wiedzę i wie, jak reagować, kiedy trzeba”; „oni wiedzą, jak pokazać dziecko z niepełnosprawnością w lepszym światle").

Nauczyciele wspomagający sądzą również, że nauczyciele wiodący, oprócz wiedzy dydaktycznej, mają przede wszystkim możliwość uskuteczniania włączającej pracy z dzieckiem ze SPE („nauczyciel wiodący czuwa nad realizacją programu"; , „jest wiele sytuacji, żeby nasze dzieci też włączać w lekcję"). Jednocześnie wyjaśniają, dlaczego jest ważne, aby nauczyciele wiodący korzystali z ich pomocy przygotowując zajęcia (,,jeśli podchodzi zbyt ambitnie [do pracy z dzieckiem ze SPE - M. S.] to sama siebie szkodzi, bo nie wiem, jak będzie go potem oceniała").

To, co wnoszą w przebieg pracy w klasie integracyjnej nauczyciele wiodący, zdaniem ich samych, to przede wszystkim umiejętność widzenia klasy jako zespołu („,muszę widzieć całą lekcję i wszystkie dzieci”; ",my nie tylko prowadzimy lekcje, też możemy pomóc z dziećmi z orzeczeniami”; „przecież ja wiem, że ona nie ogarnie jednocześnie piątki dzieci z trudnościami wiec też podchodzę i pomagam").

Słuchaczki studiów podyplomowych zauważyły natomiast, że nauczyciele wiodący, znając bardzo dobrze program nauczania i wyznaczone do pracy podręczniki, powinni eksponować w nich te treści, które wspomagają integrowanie się grupy („po postu nauczyciel wiodący ma lepszy dostęp do treści, które można bardzo fajnie wykorzystać do pracy z dzieckiem ze SPE" w grupie klasowej").

Dokładnie te same aspekty wsparcia podkreślały również studentki. Nauczyciele wiodący, w ich opinii, mają szansę widzenia jednostki lekcyjnej jako całości, a ich wskazówki mogą pomóc zaplanować lekcję dla każdego dziecka („nauczyciel wspomagający przede wszystkim ma wiedzę na temat niepełnosprawności i powinien zaproponować metody do przy z dzieckiem ze SPE i dla całej klasy, żeby wszystkich zintegrować”; „powinien umieć podpowiedzieć wiodącemu, jak pracować z dzieckiem niepełnosprawnym, jeśli trzeba powinien podesłać mu 
jakąś książkę"). Ponadto studentki zauważyły ogromne znaczenie odpowiedniej postawy nauczycieli wiodących wobec dziecka ze SPE, która może być wzorem zachowania dla całej grupy („dzieci widzą, jak traktują siebie i dzieci niepełnosprawne nauczyciele”; „wiodący powinien wcześniej poinformować wspomagającego, co będzie robił na lekcji, alby ten mógł się przygotować, czyli dostosować lekcje dla dzieci z niepełnosprawnością i strać się jakoś podczas tej lekcji zintegrować z grupą"; "wiodący powinien myśleć też o dzieciach z niepełnosprawnością, czyli wiedzieć, co zmienić, skrócić, dostosować, alby oni mogło tez uczestniczyć w lekcji").

Pogrupowane wątki i kwestie dotyczące aspektów wzajemnego wsparcia, jakie powinni okazywać sobie nauczyciele wiodący i wspomagający ilustruje tabela 2 .

Tabela 2. Aspekty wsparcia, jakie powinni okazywać sobie nauczyciele wspomagający i wiodący

\begin{tabular}{|c|c|c|c|}
\hline \multicolumn{4}{|c|}{ Najważniejsze aspekty wsparcia ze strony nauczyciela wspomagającego to: } \\
\hline $\begin{array}{c}\text { Nauczyciele } \\
\text { wspomagający }\end{array}$ & $\begin{array}{l}\text { Nauczyciele } \\
\text { wiodący }\end{array}$ & $\begin{array}{l}\text { Słuchaczki studiów } \\
\text { podyplomowych }\end{array}$ & $\begin{array}{l}\text { Studentki ostatniego } \\
\text { roku studiów } \\
\text { magisterskich }\end{array}$ \\
\hline $\begin{array}{l}\text { - Eksperci odnośnie } \\
\text { funkcjonowania } \\
\text { dzieci ze SPE }\end{array}$ & $\begin{array}{l}\text { - Wiedza odnośnie } \\
\text { funkcjonowania } \\
\text { dzieci ze SPE } \\
\text { - Możliwość zamiany } \\
\text { roli na lekcji } \\
\text { - Dostosowania, } \\
\text { oceny, rozmowy } \\
\text { z rodzicami } \\
\text { - Skuteczne rozwiąza- } \\
\text { nia trudnych sytuacji } \\
\text { wychowawczych }\end{array}$ & $\begin{array}{l}\text { - Wiedza o trudno- } \\
\text { ściach dziecka ze } \\
\text { SPE i lepsza znajo- } \\
\text { mość procesów inte- } \\
\text { gracyjnych w klasie }\end{array}$ & $\begin{array}{l}\text { - Przygotowanie do } \\
\text { pracy w nieprzewi- } \\
\text { dywalnych sytu- } \\
\text { acjach (praca bez } \\
\text { schematu) } \\
\text { - Integrowanie dzieci } \\
\text { w społeczności kla- } \\
\text { sowej }\end{array}$ \\
\hline \multicolumn{4}{|c|}{ Najważniejsze aspekty wsparcia ze strony nauczyciela wiodącego to: } \\
\hline $\begin{array}{l}\text { - Wiedza dydaktyczna } \\
\text { - Zrozumienie i otwa- } \\
\text { rtość na potrzeby } \\
\text { dziecka z SPE }\end{array}$ & $\begin{array}{l}\text { - Umiejętność angażo- } \\
\text { wania wszystkich } \\
\text { dzieci, również tych } \\
\text { z SPE } \\
\text { - Postrzegane klasy, } \\
\text {,jako całości", w któ- } \\
\text { rej są obecne potrze- } \\
\text { by dziecka ze SPE }\end{array}$ & $\begin{array}{l}\text { - Dbanie o proces dy- } \\
\text { daktyczny, program } \\
\text { nauczania i ekspono- } \\
\text { wanie treści wspo- } \\
\text { magających } \\
\text { integrowanie się } \\
\text { dzieci }\end{array}$ & \begin{tabular}{|l} 
- Widzenie jednostki \\
lekcyjnej jako całości, \\
która przy podpo- \\
wiedziach nauczy- \\
ciela wiodącego \\
może stać się lekcją \\
dla każdego dziecka \\
- Znaczenie toleran- \\
cyjnej postawy wo- \\
bec każdego dziecka
\end{tabular} \\
\hline
\end{tabular}

Źródło: Opracowanie własne.

Uzyskane dane pokazują, że wszystkie grupy zapytanych uznały, iż wsparcie nauczyciela wspomagającego w klasie integracyjnej sprowadza się przede wszystkim do dzielenia się wiedzą na temat funkcjonowania dziecka ze SPE. Studentki 
wspominały, że jego rolą jest również integrowanie klasy. Nauczyciele wiodący natomiast wymieniali inne zakresy czynności, w których chętnie przyjęliby pomoc nauczycieli wspomagających, tj. dostosowania, wspólne rozmowy z rodzica$\mathrm{mi}$, a wreszcie zastępstwo w prowadzeniu lekcji. Udział nauczyciela wiodącego to dbanie o zakres dydaktyczny, ale też umiejętność postrzegania klasy, jako całej grupy i zwrócenie uwagi na przygotowanie lekcji, w którą angażują się też dzieci ze SPE.

Okazuje się zatem, że badani widzą inną rolę nauczyciela wspomagającego i wiodącego w klasie: ten pierwszy jest ekspertem od pracy z dziećmi z orzeczeniami, a ten drugi jest odpowiedzialny za proces kształcenia. Taki dualizm w zadaniach w pracy dla pedagogów w klasie integracyjnej jest też obecny w literaturze [Bombińska-Domżał 2012], chociaż wskazuje się, że ich działania powinny być wspólnie zaplanowane i się uzupełniać [Apanel 2014]. Z jednej strony zatem, potwierdza on istnienie szkolnictwa integracyjnego jako jednej z from szkolnictwa specjalnego, z drugiej zaś, może tłumaczyć odczuwany brak konieczności wspólnego tworzenia zajęć przez dwóch pedagogów w jednej klasie integracyjnej. Być może fakt, że mają inne wykształcenie [Gajdzica 2009], inne doświadczenia (nauczyciel wiodący zazwyczaj procował w szkole masowej, a wiodący często był wcześniej pedagogiem specjalnym) powoduje, że pomimo wytycznych, wciąż odmienne postrzegają efekty edukacyjne i nieco inaczej rozumieją założenia integracji edukacyjnej. Z pewnością też nie wiele wiedzą o możliwościach, jakie daje popularne na zachodzie wspól-uczenie (co-teaching) [Friend, Cook 1996; Walsh, Snyder 1993].

\section{Współpraca nauczycieli w klasie integracyjnej}

Współpraca nauczycieli w klasie integracyjnej stanowi podstawowy warunek $\mathrm{w}$ dobrych działaniach edukacyjnych i wychowawczych. Od ich wzajemnych relacji zależą: zintegrowanie się klasy, kształtowanie interakcji między uczniami, włączanie dzieci ze SPE w codzienną pracę na lekcji, udział rodziców w życiu klasy i szkoły. Jednym z celów badania było zatem poznanie opinii badanych, jakie czynniki, ich zdaniem, mają znaczenie we współdziałaniu nauczyciela wspomagającego i wiodącego.

Przeprowadzone badanie fokusowe pokazało, że nauczyciele wspomagający uważają, iż dobre współdziałanie w zespole ma miejsce wtedy, gdy zachowania nauczycieli pracujących razem odznaczają się konsekwencją w postępowaniu wobec wszystkich dzieci i rodziców („ważne jest, żebyśmy miały wspólny front $\mathrm{w}$ trudnych sytuacjach wychowawczych i obie miały wpływ na to, jak pracować z dzieckiem"). Badane tłumaczą, dlaczego jest to bardzo ważne w ich współpracy („,nie może być tak, że rodzic idzie najpierw do jednej, a potem do drugiej, bo rodzice często wykorzystują taką sytuację przeciwko nauczycielom"). Badane pod- 
kreślały też konieczność odpowiedniego podziału obowiązków, na który składają się tworzenie zajęć, wspólne ocenianie i angażowanie dzieci w tok lekcji („,ważne, żeby było z góry powiedziane, co każda z nas ma robić"; "wspólne oceniania i konsultowanie się jest niezbędne"). Uwypuklali też znaczenie dobrze dobranej pary nauczycieli oraz sugerowali potrzebę opieki superwizora nad zespołami pracującymi w grupie integracyjnej (,,czasami jest trudno, bo pary są z góry narzucane"; ,'dobrze, jak ktoś oceni i powie, co trzeba zmienić') .

Nauczyciele wiodący natomiast, zwracali uwagę na współdziałanie w zadaniach edukacyjnych i terapeutycznych, które polegałoby na zaangażowaniu nauczyciela wspomagającego we wszystkie aspekty pracy, tj. robienie wspólne gazetki, przygotowanie do uroczystości szkolnych („nie może być tak, że nauczyciel wspomagający jest nieobecny na próbach i uroczystościach szkolnych, na których występują dzieci z orzeczeniami"). Dla tej grupy badanych ogromnie znaczenie ma obecność głębszych relacji z nauczycielem wspomagających, nie tylko na poziomie zawodowym („,zzęsto gadamy po lekcjach, rodzą się wtedy pomysły na aktualne lekcje”; ,"dobrze wiedzieć, że jak czuję, że już nie dam rady, to mogę liczyć, że ona pociągnie lekcję").

Słuchaczki stadiów podyplomowych, oprócz aspektu partnerskiego działania $\mathrm{w}$ zespole, poruszały też konieczność unikania stereotypowego postrzegania wspólpracy („nauczyciel wspomagający to partner, a nie intruz pomijany w uroczystościach klasowych"; ,"nauczyciel wspomagający chce wspierać w dobrej pracy, a nie przeszkadzać, wchodzić $w$ kompetencje, jak myślą niektórzy nauczyciele wiodący"). Studentki zaś zauważyły, podobnie jak osoby z pozostałych grup biorących udział w badaniu, że relacje poza szkołą, tzw. „lubienie się" powoduje lepsze porozumiewanie się na lekcji („widziałam nauczycielki, które pracowały razem od lat, były blisko psychicznie i porozumiewały się bez słów i to powodowało, ze każda wiedziała, co do niej należy”; , widać było, że nauczycielki się lubią nie tylko w szkole to przenikało na ich wspólną pracęe"). Również podkreślały, jakie jest znaczenie równości nauczycieli w prawach, obowiązkach i przywilejach („,nie jest dobrze, że nadal tylko wychowawca klasy, czyli nauczyciel wiodący z tego tytułu ma dodatek", ponieważ "to już od razu ustawia tę relację ze strony wspomagającego, tobie więcej płacą, jesteś odpowiedzialna z całość").

W odpowiedzi na pytanie, co może mieć wpływ na poprawę współpracy pedagogów w klasie integracyjnej, nauczyciele wspomagający wskazali możliwość skorzystania z superwizji oraz organizowanie spotkań integracyjnych, które mogłyby pogłębić relacje nauczycieli („moim zdaniem, ktoś powinien czuwać nad zespołami integracyjnymi. Jeśli nie ma możliwości spotkań poza szkołą to powinna być możliwość zmiany partnera, bo wielu nauczycieli jest z przypadku"). Ich zdaniem, dobrym rozwiązywaniem byłyby też szkolenia i wyjazdy integracyjne, na których można by było odreagować stres i wszelkie obciążenia związane 
z pracą w szkole („,spotkanie integracyjne to dobry pomysł, bo to możność dogadania się na płaszczyźnie pozaszkolnej”; „,spotkania na luzie pozwalają odreagować stres i popatrzeć na siebie z innej strony").

Nauczyciele wiodący natomiast sugerują konieczność jasno określonych obowiązków nauczyciela wspomagającego („nie chcemy tego robić sami”) i odgórne, "ministerialne" ustalenie obszarów współpracy. Nauczyciele wyjaśniają też, dlaczego to jest tak ważne w ich pracy („przy jasnych ustaleniach, nie byłoby tak, że opinie piszę sama, a że robię to z nauczycielem wspomagającym, to nasza wspólna działka, żeby nie było, że ja tego wymagam”; „przykład musi iść z góry, to znaczy to, że jesteśmy jednością").

Podobnie myślą słuchaczki studiów podyplomowych. Ich zdaniem, powszechnie znane zasady współpracy pomogłyby uniknąć nieporozumień („,powinny być ustalone zasady, w czym mam pomóc, a w czym nie"), a wspólne wyjazdy byłyby okazją na lepsze poznanie się („bo nie ma gdzie 'spróbować tej relacji, kiedy brakuje spotkań po lekcjach; podczas pracy po postu nie ma na to czasu"). Dodatkowo widzą też konieczność większego, bardziej kreatywnego zaangażowania się nauczycieli w proces uczenia dzieci („dobrej współpracy zawsze pomaga postawa, że robię więcej dla dobra wspólnego, niż mi przypisano").

Studenci zaś wskazywali na niezbędność większej otwartości na punkt widzenia drugiej strony, "zrównania” pozycji nauczyciela wspomagającego w klasie integracyjnej („nauczyciele muszą wiedzieć, że są równi w swojej pracy; raz jeden zajmuje się całą klasą, a w razie potrzeby drugi"). Dodatkowo, tak jak pozostali uczestnicy badania, wskazywali na niezbędność odgórnie ustalanych warunków współpracy, ale też możliwość zmiany partnera (większa elastyczność w tym względzie), jeśli współpraca się nie układa („nauczyciele powinni wiedzieć, co do nich należy, a potem wcześniej obgadać wszystko w szczegółach"; „dyrektor powinien rozmawiać z nauczycielami o ich oczekiwaniach i dokonać zmiany, gdy współpraca się nie układa").

Zestawienie najistotniejszych cech dobrej współpracy nauczycieli wspomagających i wiodących w klasie integracyjnej, które wymieniali uczestnicy badania fokusowego zawiera tabela 3.

Wywiady z badanymi pokazują, że dla wszystkich zapytanych dobra współpraca polega na partnerstwie $\mathrm{w}$ prawach i obowiązkach, jakie mają nauczyciele $\mathrm{w}$ klasie integracyjnej. Pedagodzy powinni być razem obecni podczas trudnych sytuacji wychowawczych, przy wykonywaniu dodatkowych zajęć pozalekcyjnych i mają być po równo wynagradzani. Studentki i nauczyciele wiodący zauważyli, że bardzo duże znaczenie dla współpracy pedagogów mają przyjacielskie relacje pozalekcyjne. Dla nauczycieli wspomagający dobór par również odgrywa dużą rolę. Wszyscy zapytani ocenili, że aby poprawić współpracę pedagogów należy stworzyć ogólne zasady współdziałania oraz dać możliwość poprawy pracy poprzez systematyczną jej ocenę. 
Zdaniem badanych to, co utrudnia współpracę w klasie integracyjnej to nierówny podział obowiązków i „brak wspólnego frontu” w pracy z rodzicami. Okazuje się, że uzyskane wyniki tylko częściowo pokrywają się z danymi na temat trudnych sytuacji w klasie w opinii nauczycieli [Gajdzica 2011]. Zdaniem nauczycieli wspomagających, nauczycieli wiodących, słuchaczek studiów podyplomowych i studentek ostatniego roku studiów, każdej złożonej sytuacji metodycznej i trudnej relacji z rodzicami można zaradzić, jeśli nauczyciele są partnerami i mogą na siebie liczyć.

Tabela 3. Cechy dobrej współpracy nauczyciela wspomagającego i wiodącego

\begin{tabular}{|c|c|c|c|}
\hline \multicolumn{4}{|c|}{ Dobra współpraca wtedy, gdy: } \\
\hline $\begin{array}{l}\text { Nauczyciele } \\
\text { wspomagający }\end{array}$ & $\begin{array}{l}\text { Nauczyciele } \\
\text { wiodący }\end{array}$ & $\begin{array}{l}\text { Słuchaczki studiów } \\
\text { podyplomowych }\end{array}$ & $\begin{array}{l}\text { Studentki ostatniego } \\
\text { roku studiów } \\
\text { magisterskich }\end{array}$ \\
\hline $\begin{array}{l}\text { - Konsekwencja wy- } \\
\text { chowawcza (wspól- } \\
\text { ny front) } \\
\text { - Współpraca i rów- } \\
\text { ność w działaniach } \\
\text { - Dobór par } \\
\text { - Superrewizje }\end{array}$ & $\begin{array}{l}\text { - Współdziałanie } \\
\text { w zadaniach eduka- } \\
\text { cyjnych i terapeuty- } \\
\text { cznych } \\
\text { - Relacje głębsze niż } \\
\text { tylko profesjonalne } \\
\text { (wyczuwanie siebie } \\
\text { nawzajem) }\end{array}$ & $\begin{array}{l}\text { - Dbanie o utrzymanie } \\
\text { równowagi i zaufa- } \\
\text { nia w działaniach } \\
\text { nauczycieli w klasie; } \\
\text { nauczyciele "partne- } \\
\text { rzy" } \\
\text { - Unikanie schematy- } \\
\text { cznego myślenia }\end{array}$ & $\begin{array}{l}\text { - Osobiste pozainsty- } \\
\text { tucjonalne relacje, } \\
\text { porozumienie się } \\
\text { „bez słów” } \\
\text { - Równość w prawach } \\
\text { i obowiązkach (rów- } \\
\text { nież finansowa) }\end{array}$ \\
\hline \multicolumn{4}{|c|}{ Poprawa współpracy przez: } \\
\hline $\begin{array}{l}\text { - Spotkania integra- } \\
\text { cyjne } \\
\text { - Relacje, pozainsty- } \\
\text { tucjonalne } \\
\text { - Możliwość odreago- } \\
\text { wania stresu, obcią- } \\
\text { żenia pracą w szkole } \\
\text { z dziećmi ze SPE }\end{array}$ & $\begin{array}{l}\text { - Jasno określone obo- } \\
\text { wiązki nauczyciela } \\
\text { wspomagającego } \\
\text { _ + ustalenie obsza- } \\
\text { rów współpracy }\end{array}$ & $\begin{array}{l}\text { - Odgórnie ustalone } \\
\text { ramy, zasady, obsza- } \\
\text { ry współpracy na- } \\
\text { uczyciela wiodącego } \\
\text { i wspomagającego } \\
\text { - Więcej spotkań na- } \\
\text { uczycieli, również } \\
\text { poza szkołą } \\
\text { - Postawa „robię wię- } \\
\text { cej dla wspólnego } \\
\text { dobra, niż mi przypi- } \\
\text { sano" }\end{array}$ & $\begin{array}{l}\text { - Otwartość na punkt } \\
\text { widzenia drugiej } \\
\text { strony } \\
\text { - Praca na zrówna- } \\
\text { niem pozycji na- } \\
\text { uczyciela } \\
\text { wspomagającego } \\
\text { w klasie integracyjnej } \\
\text { - Odgórne ustalanie wa- } \\
\text { runków współpracy } \\
\text { - Możliwość zmiany } \\
\text { partnera }\end{array}$ \\
\hline
\end{tabular}

Źródło: Opracowanie własne.

\section{Podsumowanie}

Najważniejszym wnioskiem przeprowadzonego badania fokusowego jest postulat nauczycieli wiodących i wspomagających dotyczący wprowadzenia zasad współpracy, praw i obowiązków nauczycieli w klasie integracyjnej. Nauczyciele wiodący, nauczyciele wspomagający, słuchaczki studiów podyplomowych 
i studentki podkreślali konieczność wspólpracy opartej na partnerstwie, otwartość na opinie, doświadczenie i kompetencje drugiej strony oraz znaczenie pozaprofesjonalnych relacji nauczycieli. Zgłoszone postulaty mogą stanowić przesłankę do zaprojektowania badań ilościowych na dużej próbie, które miałyby na celu poznanie oczekiwań, potrzeb i zasad współpracy nauczyciela wspomagającego i wiodącego, a które mogłyby stanowić wskazówki dla odgórnie ustalonych ram współpracy.

Uzyskanie informacji na temat warunków dobrej współpracy nauczycieli w kasie integracyjnej, które było celem przeprowadzonego badania fokusowego, zostało też ujęte $\mathrm{w}$ założeniu teoretycznym stanowiącym próbę uzasadnienia tezy, że są jakieś „wspólne i swoiste” obszary ich partnerskiego działania. Okazuje się jednak, że w wypowiedziach badanych zaciera się szczególna potrzeba wyodrębniania specyficznych dla poszczególnych nauczycieli zakresów działania $\mathrm{w}$ klasie integracyjnej. Jednocześnie, z jednej strony, nauczyciele wiodący to specjaliści od spraw przebiegu dydaktycznego lekcji, programów, planów i podręczników, a nauczyciele wspomagający to eksperci od integrowania całej grupy i tworzenia klasy jako wspólnoty osób z różnymi możliwościami, trudnościami i potrzebami. $Z$ drugiej strony zaś, zdaniem badanych, ich działania powinny się przeplatać: w przypadku dostosowywania lekcji dla dzieci ze SPE, konieczności oceny uczniów, podczas rozmowy z rodzicami iw sytuacjach gorszej kondycji psychicznej jednego z nauczycieli.

Wydaje się, że postulaty dotyczące odgórnie określonych zasad współpracy, praw i obowiązków mają na celu uprawomocnienie potrzeby równowagi we współpracy między nauczycielami. W takiej modelowej klasie nie ma dominującego podziału na nauczyciela wiodącego (tego pierwszego) i nauczyciela wspomagającego (tego, który jest „na dokładkę"), nie ma wychowawcy i "tego drugiego". Co więcej, nie ma też tego, który odpowiada za całość, jako "pierwszy” i tego, co może skończyć pracę wcześniej, bo dzieci, które mają orzeczenie o potrzebie kształcenia specjalnego poszły już do domu. W klasie integracyjnej pracuje dwóch nauczycieli, którzy, chociaż ich wykształcenie pozwala patrzeć na proces nauczania $\mathrm{w}$ kasie integracyjnej pod innym kątem, nie różnią się w pracy w szkole pod względem obowiązków, zadań, ani uzyskiwanych dochodów. Kwestia, czy takie rozwiązania są możliwe pozostaje wciąż pytaniem otwartym.

\section{Bibliografia}

Ablewicz A. (2010), Hermeneutyka i fenomenologia a pedagogika [w:] Podstawy metodologii badań w pedagogice, red. S. Palka, Gdańskie Towarzystwo Psychologiczne, Gdańsk. 
Al-Khamisy D. (2013), Edukacja wtączająca edukacją dialogu. W poszukiwaniu modelu edukacji ucznia ze specjalnymi potrzebami edukacyjnymi, Wydawnictwo Akademii Pedagogiki Specjalnej, Warszawa.

Apanel D. (2014), Teoria i praktyka kształcenia integracyjnego osób z niepetnosprawnością w Polsce w latach 189-2014, Wydawnictwo Adam Marszałek, Torun.

Bauwens J., Hourcade J. J., Friend M. (1989), Cooperative teaching: A model for general and special education integration, "Remedial and Special Education”, 10(2).

Bayliss P. (1996), Modele integracji pedagogicznej [w:] Wychowanie i nauczanie integracyjne, red. J. Bogucka, M. Kościelska, Wydawnictwo STO, Warszawa.

Bąbka J. (2001), Edukacja integracyjna dzieci petnosprawnych i niepetnosprawnych. Założenia i rzeczywistość, Fundacja „Humaniora”, Poznań.

Bobińska-Domżał A. (2014), Wspótpraca pedagoga specjalnego i nauczyciela przedmiotu w procesie terapii i edukacji uczniów z zaburzeniami ze spektrum autyzmu w ksztatceniu integracyjnym [w:] Osoba ze stanami ze spektrum autyzmu. Możliwości aktywnego życia, red. J. Kossewska, Wydawnictwo JAK, Poznań.

Bombińska-Domżał A. (2012), Realizacja działań edukacyjnych przez pedagoga specjalnego i nauczyciela przedmiotu w klasie integracyjnej [w:] Aktywizacja ucznia z niepetnosprawnościa w szkole różnych obszarach jego edukacji, red. A. Mikrut, P. Majewicz, Wydawnictwo Naukowe UP, Kraków.

Chrzanowska I. (2015), Pedagogika specjalna. Od tradycji do wspótczesności, Oficyna Wydawnicza "Impuls”, Karków.

Chrzanowska I., Jachimczak B. (2015), Praca wychowawcza w grupie zróżnicowanej - uczeń ze specjalnymi potrzebami edukacyjnymi w szkole ogólnodostępnej [w:] Wychowawcze i społeczno-kulturowe kompetencje wspótczesnych nauczycieli. Wybrane konteksty, red. J. Pyżalski, Wydawnictwo TheQ studio, Łódź.

Douglas S.N., Chapin S.E., Nolan J.F. (2015), Special Education Teachers' Experiences Supporting and Supervising Paraeducators. Implications for Special and General Education Settings, Teacher Education and Special Education, "The Journal of the Teacher Education Division of the Council for Exceptional Children", 39(1).

Dryżałowska G. (2001), Obecność teorii "wspólne i swoiste" Aleksandra Hulka we wspótczesnej pedagogice [w:] Paradygmaty i przeobrażenia edukacji specjalnej w świetle dorobku profesora Aleksandra Hulka, red. G. Dryżałowska, Wydawnictwo Akademickie Żak. Warszawa.

Dukaczewska-Nałęcz A. (1999), Zogniskowane wywiady grupowe - jakościowa technika badawcza [w:] Spojrzenie na metodę. Studia z metodologii badań socjologicznych, red. H. Domański, K. Lutyněska, A.W. Rostocky, IFiS PAN, Warszawa.

Fielding-Barnsley R. (2005), The attributes of a successful Learning Support Teacher in Australian inclusive classrooms, "Journal of Research in Special Educational Needs", 5(2).

Friend M., Cook L. (1996), Interactions: Collaboration skills for school professionals, White Plains, Longman.

Gajdzica Z. (2007), Perspektywa badan nad systemem ksztatcenia uczniów niepetnosprawnych w Polsce-analiza możliwej i podejmowanej problematyki badań [w:] Rozwój i funkcjonowanie osób niepetnosprawnych. Konteksty edukacyjne i prawne, red. Z. Gajdzica, Oficyna Wydawnicza „Impuls”, Kraków. 
Gajdzica Z. (2009), Wykształcenie nauczycieli pracujacych w klasach integracyjnych [w:] Społeczne i edukacyjne uwarunkowania rozwoju oraz funkcjonowania dzieci i młodzieży z niepetnosprawnościq, red. Z. Gajdzica, Oficyna Wydawnicza „Impuls”, Kraków.

Gajdzica Z. (2010), Kilka uwag na temat teorii kształcenia integracyjnego, „Niepełnosprawność", nr 3.

Gajdzica Z. (2011), Sytuacje trudne w opinii nauczyciela klas integracyjnych, Oficyna Wydawnicza „Impuls”, Kraków.

Gajdzica Z. (2011), Sytuacje trudne w opinii nauczycieli klas integracyjnych, Oficyna Wydawnicza „Impuls”, Karków.

Grzegorzewska M. (1996), Listy do młodego nauczyciela. Cykl I, Wydawnictwo APS, Warszawa.

Grzegorzewska M. (1989), Znaczenie wychowawcze osobowości nauczyciela [w:] Wybór pism, M. Grzegorzewska, PWN, Warszawa.

Hulek A. (1988), Wspólne i swoiste zagadnienia rewalidacji [w:] Pedagogika rewalidacyjna, red. A. Hulek, PWN, Warszawa.

Janiszewska-Nieścioruk Z. (1999), Uwarunkowania efektów społecznej integracji [w:] Z teorii i badań społecznej integracji dzieci niepetnosprawnych, red. A. Maciarz, Oficyna Wydawnicza „Impuls”, Kraków.

Kędzierska J. (2010), Planowanie pracy rewalidacyjnej z dziećmi niewidomym i słabowidzącymi w szkłach ogólnodostępnych [w:] Dajmy szansę niewidomym i niedowidzacych. Poradnik metodyczny dla nauczycieli, red. T. Żółkowska, Wydawnictwo OR TWP, Szczecin.

Koć-Seniuch G. (2000), Wspótczesne integracyjne systemy i modele kształcenia [w:] Nauczyciel i uczniowie w dyskursie edukacyjnym: wybrane problemy do zajęć konwersatoryjnych z pedagogiki, red. G. Koć-Seniuch, A. Cichocki, Wydawnictwo „Trans Humana”, Białystok.

Konecki K. (2000), Studia z metodologii badań jakościowych. Teoria ugruntowana, PWN, Warszawa.

Krueger R.A. (1994), Focus groups: A Practical Guide for Applied Research, Thousand Oaks, CA, Sage.

Kubinowski D. (2010), Jakościowe badania pedagogiczne. Filozofia. Metodyka. Ewaluacja, Wydawnictwo UMCS, Lublin.

Lisek-Michalska J. (2013), Badania fokusowe. Problemy metodologiczne i etyczne, Wydawnictwo Uniwersytetu Łódzkiego, Łódź.

Maciarz A. (1987), Integracja społeczna dzieci niepetnosprawnych, WSiP, Warszawa.

Maciarz A. (1992), Wiedza i przekonania o dzieciach niepetnosprawnych nauczycieli szkót masowych [w:] Uczeń niepetnosprawny w szkole masowej, red. A. Hulek, B. Grochmal-Bach, Wydawnictwo WSiP, Kraków.

Maison D. (2001), Zogniskowane wywiady grupowe. Jakościowa metoda badań marketingowych, PWN, Warszawa.

Palak Z., Bujnowska A. (2008), Kompetencje pedagoga specjalnego. Aktualne wyzwania teorii i praktyki, Wydawnictwo UMCS, Lublin.

Rzedzicka K. D. (2000), Wspólna edukacja: między asymilacja a otwarciem na inność [w:] Człowiek, szkoła, wspólnota: w kręgu edukacji społecznej, red. M. Mendel, Wydawnictwo Adam Marszałek, Torun. 
Sadowska S. (2016), Ksztatcenie osób niepetnosprawnych uwikłane w wartości-od polityki zaangażowania moralnego do praktyk edukacyjnych zaangażowanych w sprawiedliwość, "CzłowiekNiepełnosprawność-Społeczeństwo", nr 3(33).

Scott T.M. (2017), Training Classroom Management With Preservice Special Education Teachers: Special Education Challenges in a General Education World, Teacher Education and Special Education, "The Journal of the Teacher Education Division of the Council for Exceptional Children", 40(2).

Sipowicz K., Pietras T. (2017), Wprowadzenie do pedagogiki inkluzyjnej (włączającej), Wydawnictwo Continuo, Wrocław.

Staczewska A., Hodkinson A., Adams G. (2012), Conceptions of inclusion and inclusive Education: a critical examination of the perspectives and practices of teachers in Poland, "Journal of Research in Special Educational Needs", 3(12).

Szumski G. (1996), Integracyjne ksztatcenie niepetnosprawnych: sens i granice zmiany edukacyjnej, Wydawnictwo Akademii Pedagogiki Specjalnej, Warszawa.

Szumski G. (2006), Edukacja inkluzyjna - geneza, istota, perspektywy, „Kwartalnik Pedagogiczny", $\operatorname{nr} 1(199)$.

Szumski G. (2014), Edukacja włączająca - niedokończony projekt, „Ruch Pedagogiczny”, nr 4.

Walsh J.J., Snyder D. (1993), Cooperative teaching: An effective model for all students, Paper presented at the annual convention the Council for Exceptional Children, San Antonio.

Rozporządzenie Ministra Edukacji Narodowej z dnia 1 sierpnia 2017 r., w sprawie warunków organizacji kształcenia, wychowania i opieki dla dzieci z młodzieży niepełnosprawnych, niedostosowanych społecznie i zagrożonych niedostosowaniem społecznym (Dz. U. z 2017 r., poz. 1578).

Rozporządzenie Ministra Edukacji Narodowej z dnia 9 sierpnia 2017 r., w sprawie szczegółowych kwalifikacji wymaganych od nauczycieli (Dz. U. z 2017 r., poz. 1575). 